Goldschmidt 2021 Abstract

https://doi.org/10.7185/gold2021.3214

\section{Potential Role of a Novel Strain of Citrobacter sp. in Controlling Arsenic Speciation in Groundwater}

\author{
AKSHAT VERMA ${ }^{1,2}$, PREM ANAND MURUGAN ${ }^{2}$, \\ SARAVANAN MATHESHWARAN ${ }^{2}$ AND ABHAS SINGH ${ }^{1,2}$ \\ ${ }^{1}$ Indian Institute of Technology Kanpur \\ ${ }^{2}$ Indian Institute of Technology, Kanpur (IITK) \\ Presenting Author: avermar@iitk.ac.in
}

Elevated arsenic (As) in groundwater is a matter of serious concern in many countries due to its toxic effects on human health. In groundwater, As concentration is primarily controlled by complex site-specific biogeochemistry. Although As contamination in groundwater is mainly attributed to inorganic sources, such as iron (oxy)hydroxides, yet the exact mechanisms on how the biotic components influence As speciation are not clearly understood. This study aims to identify potential controls on arsenic speciation in polluted aquifers by understanding the interaction of arsenic-resistant bacteria with inorganic arsenic sources. A novel strain of Citrobacter sp. (AVAS IITK SM2) was isolated from groundwater in Kanpur, India, at conditions that were oxidizing with respect to arsenic speciation. The strain was enriched in Lysogeny broth and minimal salt media, and was subjected to morphological, physiological, biochemical, and molecular characterizations. Redox transformation efficiency of this Citrobacter $s p$. was determined through its interactions with either dissolved $\mathrm{As}(\mathrm{V})$ or $\mathrm{As}(\mathrm{III})\left[0-500 \mathrm{mg} \mathrm{L}^{-1}\right]$ under batch conditions. Additionally, bio-mobilization of As was investigated in a batch containing As-sorbed-goethite $\left(\sim 26 \mathrm{mg} \mathrm{g}^{-1}\right)$ and $A V A S$ IITK SM2. Arsenic speciation was measured using ion chromatography coupled with ICPMS. Results indicated that this rod-shaped isolate can tolerate high concentrations of $\mathrm{As}(\mathrm{V})$ and $\mathrm{As}(\mathrm{III})$. Further, the isolate can reduce $\mathrm{As}(\mathrm{V})$ to $\mathrm{As}(\mathrm{III})$ and mobilize arsenic [ $\sim 7 \mathrm{mg} \mathrm{L}^{-1}$ as As(III); Fig.1a] from As-sorbedgoethite in the presence of glucose. whole genome sequences of g-DNA and plasmids confirmed the presence of ars arsenic operon system in this Citrobacter $s p$.

To understand the bacterial metabolism and its planktonic growth under environmental conditions, time-dependent biofilm formation was also investigated using crystal-violet and microscopic analyses in the presence of varying As(III) [0-1000 $\left.\mathrm{mg} \mathrm{L}^{-1}\right]$ and $\mathrm{As}(\mathrm{V})$ concentrations $\left[0-5000 \mathrm{mg} \mathrm{L}^{-1}\right]$. Results indicated that this strain can effectively form biofilm, and it preferred to stay attached to a surface with increase arsenic concentrations and time (Fig. 1b). These results would likely enhance our understanding of $\mathrm{As}(\mathrm{V})$-reducing bacterial strains in controlling arsenic speciation in oxidizing groundwaters (Fig.1c).

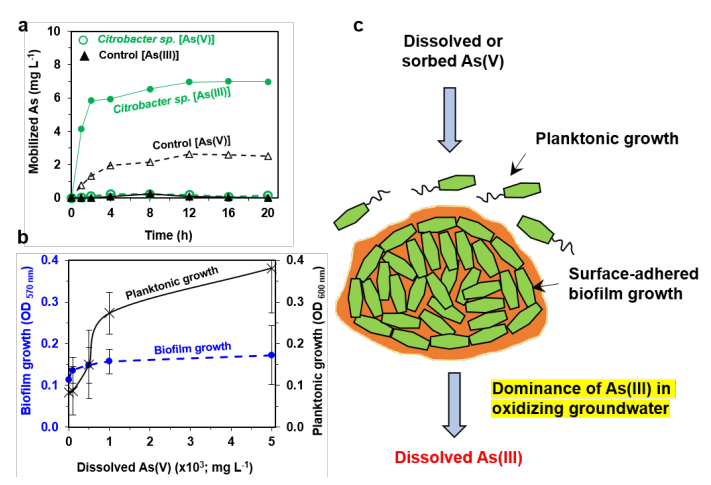

Fig.1. Arsenic biotransformation by Citrobacter sp. AVAS IITK SM2. (a) Evolution of dissolved arsenic from arseno-goethite in the absence (Control) and presence (Citrobacter sp.) of AVAS IITK SM2 (b) Variation of surface-adhered biofilm and planktonic growth with increasing dissolved $A s(V)$ concentration $\left(0-5000 \mathrm{mg} \mathrm{L}^{-1}\right)$ after $8 \mathrm{~d}$, and (c) Schematic of $\mathrm{As}(\mathrm{V})$ reduction to $\mathrm{As}(\mathrm{III})$ 